\title{
QUALITY AND METHODS OF ADULTERATION OF MEAT AND FISH PRODUCTS ON THE POLISH MARKET IN 2010-2020
}

\author{
Stanistaw Kowalczyk $k^{l}$ \\ ${ }^{1}$ Institute of Markets and Competition, Collegium of Business Administration, \\ Warsaw School of Economics, Warsaw, Poland
}

\begin{abstract}
Background. Globalisation is the direct or indirect source and cause of many economic, social, political and cultural processes and phenomena. These processes also affect agribusiness and food production. One of the important developments in recent decades is the ever-increasing scale of food adulteration. Its consequence is a reduction in the level of food safety, both in its health and economic aspects. The latter is due to the presence of impaired, or even adulterated, food on the market, which exposes consumers to non-equivalent exchanges. Sectors particularly vulnerable to these illegal trade practices include meat and fish products.

Objective. The aim of the article is to identify the dominating methods/categories of food adulteration using the example of the Polish market for the food production sectors of meat and fish.

Material and methods. The research was conducted using data from the Agricultural and Food Quality Inspection (AFQI), the official food control institution responsible for quality and food adulteration controls in Poland. The study covered the period from 2010 to 2020.

Results. Research has shown an exceptionally significant level and diversity of methods of adulterating meat and fish products. These products are adulterate much more often than other food products. The conducted research has shown many methods and ways of adulterating both meat and fish products. It is worth emphasizing that the greater concentration of counterfeiting methods concerns meat products.

The study revealed an extremely significant variety of adulterating methods for meat and fish products, significantly beyond those typically cited in the literature.

Conclusions. The results of the research indicate the need to intensify official food controls on the Polish market. In particular, this should apply to the group of meat and fish products due to their high level of adulteration.
\end{abstract}

Key words: food, food quality, food adulteration, meat products, fish products

\section{STRESZCZENIE}

Wprowadzenie. Globalizacja jest bezpośrednim, bądź pośrednim źródłem i przyczyną wielu procesów oraz zjawisk gospodarczych, społecznych, politycznych i kulturowych. Procesy te dotykają także agrobiznesu oraz produkcji żywności. Jednym $\mathrm{z}$ ważnych $\mathrm{w}$ ostatnich dekadach zjawisk jest stale narastająca skala fałszerstw żywnościowych. Jego konsekwencją jest obniżenie poziomu bezpieczeństwa żywności, zarówno w aspekcie zdrowotnym, jak i ekonomicznym. W tym drugim wynikającym z obecności na rynku żywności o obniżonej jakości, lub wręcz zafałszowanej, co naraża konsumentów na nie ekwiwalentność wymiany w trakcie czynionych zakupów. Sektory szczególnie narażone na te nielegalne praktyki handlowe obejmują produkty mięsne i rybne.

Cel. Celem artykułu jest identyfikacja dominujących metod/kategorii fałszowania żywności na przykładzie rynku polskiego w sektorach produktów mięsnych i rybnych.

Material i metody. Badania przeprowadzono na podstawie danych Inspekcji Jakości Handlowej Artykułów RolnoSpożywczych (Agricultural and Food Quality Inspection - AFQI), instytucji urzędowej kontoli żywności odpowiadającej w Polscce za kontrole w zakresie jakości oraz zafałszowania żywności. Badaniami objęto okres $2010-2020$.

Wyniki. Badania wykazały wyjątkowo znaczący poziom oraz zróżnicowanie metod fałszowania produktów mięsnych i rybnych. Produkty te są fałszowane znacznie częściej, niż inne artykyły spożywcze. Przeprowadzone badania wykazały wiele metod oraz sposobów fałszowania zarówno produktów mięsnych, jak i rybnych. Warto podkreślić, że większa koncentracja metod fałszowania dotyczy produktów mięsnych. Badania wykazały duże zróżnicowanie metod fałszowania produktów miesnych i rybnych na rynku polskim, znacznie wykraczające poza typowo stosowane metody podawane w literaturze.

Corresponding author: Stanisław Kowalczyk, Institute of Markets and Competition, Collegium of Business Administration, Warsaw School of Economics, Al. Niepodległości 162, 02-554 Warsaw, Poland; e-mail: skowal1@sgh.waw.pl 
Wnioski. Uzyskane wyniki wskazują na konieczność intensyfikacji urzędowych kontroli żywności na rynku polskim. W szczególności powinno to odnosić się do grupy przetworów mięsnych i rybnych z uwagi ich wysoki poziom zafałszowania.

Słowa kluczowe: żywność, jakość żywności, fatszowanie żywności, produkty mięsne, produkty rybne

\section{INTRODUCTION}

Processes taking place in the world under the influence of globalization lead to many new previously unknown, or which occur to a limited extent, events and phenomena. They are both positive and negative in their nature $[9,12,34,39]$. The first group includes freedom of trade, capital flows, new investment and innovation opportunities, and easier access to education and culture. The second group, on the other hand, includes the growth of economic crime, easy inter-regional or even global transmission of crisis events, and the increased risk of spreading pandemics, as we have all seen in 2020.

The above processes in agribusiness and food production occur according to the following sequence: (i) the development of global trade makes the path "from farm to fork" longer, (ii) longer distribution channels (growth in the number of intermediaries), (iii) an increasingly anonymous market, (iv) more and more products of other climate zones in the average consumer's diet, (v) more and more products from the native climate zone produced in other zones and regions of the world in the average diet, (vi) an increasing tendency to market food which is not nutritious or even dangerous to health, (vii) increasing difficult in/of traceability and, as a result, more and more adulterated food and reduced food security and food safety. The globalisation of the food chain has led to greater complexity and thus less consumer confidence in how and where food is grown, harvested and processed, and by whom.

In this situation, the risk of placing adulterated (including mislabelled) and impaired quality food on the market increases. This was indisputably proven by the horsemeat scandal in 2013, and it has been confirmed by subsequent actions within the framework of the "OPSON" operation implemented since $2011[21]^{1}$.

A significant increase in identified cases of food adulteration and contamination, otherwise known as food incidents, occurred in the late 20th century $[17,33]$. The author's own analysis of more than 700 significant incidents, measured by the number of diagnosed cases of illness, or the size of the adulterated food batch questioned shows that in the second decade of the 21st century there were in the world on average more than two times as many incidents per

1 Operation OPSON is a Europol INTERPOL joint operation targeting fake and substandard food and beverages carried out since 2011. year as there were in the first decade of this century. This gives the grounds for the theory of the world's socalled second wave of food counterfeiting. After the first one that took place in the mid-19th century [24]. While the primary cause of the first wave was rapidly progressing industrialisation and the consequent emergence of the anonymous consumer. The cause of the second wave is progressive globalisation, which dramatically lengthens supply chains, making the food market more spatially dispersed and even more anonymous, thus exposing it to the risk of introducing adulterated or reduced-quality food.

Meat processing is one of the sectors particularly vulnerable to food adulteration $[6,7,10,25,35]$.

According to the study by Di Pinto et al., in Italy in 2014 at the Department of Veterinary Medicine, University of Bari Aldo Moro [10], as much as $57 \%$ of the controlled samples of meat products were adulterated. Out of 36 products declared as made entirely from poultry meat, 20 (55.5\%) additionally contained beef and pork, and out of the 12 products that according to the label were made from pork, as many as $75 \%$ contained beef. In contrast, according to Tembe, Mukaratirwa and Zishiri [35], out of 40 tested samples, $26(65 \%)$ were adulterated with meat not shown on the label including $100 \%$ poultry products and $60 \%$ sheep products, and according to Cawthorn et al. (tests in the Republic of South Africa, in 2012) [7], out of 139 products as many as $95(68 \%)$ were adulterated.

Fish processing and fish products are also among the sectors vulnerable to adulteration and counterfeiting. In this case, it is not only consumers who are exposed to the effects of illegal practices (by offering toxic fish species $^{2}$ and fish grown in polluted and contaminated water bodies), but also the environment and fish resources (overharvesting of endangered species, the use of unauthorised fishing methods, fishing in protected waters [18].

Counterfeit fish products are commonly included in the food category most exposed to fraud and adulteration. According to the European Commission, fish products rank second on the list of the most adulterated food products [17] $]^{3}$, while according to INTERPOL-Europol (Operation OPSON) these were third in 2015 [19], fifth in 2017 [20] and ninth in

2 Toxic fish species - some species of puffer fish, scombroid fish, escolar or oilfish, and ciguatoxic fish species.

3 Olive oil is the product most vulnerable to counterfeiting, according to the same report. 
2019 [21], which may indicate an improvement in the quality and safety of fish products, but does not mean, however, that the status is satisfactory.

The fish sector is in some ways unique within the food industry. The problem of legality and irregularities concerns the entire supply chain, from the acquisition of raw materials to the final product. Illegal fishing accounted for $21 \%$ of total catches in the 1980 s, dropping to $18 \%$ by the beginning of the 2000 s, which is only 3 percentage points. However, this followed reductions in illegal fishing in a few regions, such as the Northeast Pacific, Southeast Atlantic, and Northeast Atlantic, as other regions experienced increases [1]. The consequence of this is the situation in the subsequent links of the fish chain. Almost half of Argentine sea bass comes from outside area 87 where it is traditionally caught [26]. Between 2009 and 2014 as much as $65 \%$ of fish offered in markets and bazaars in Sardinia (Italy) was mislabelled (incorrect species) [27]. In Canada and the USA on average about $40 \%$ of fish products are mislabelled [31], with China at up to $85 \%$ [41].

Showing the place of meat and fish products in the collection of food incidents, and more specifically cases of adulteration meat and fish products on the Polish market, is possible on the basis of the EU databases RASFF (Rapid Alert System for Food and Feed) and AAC-FF system (Administrative Assistance and Cooperation System - Food Fraud; from 2019 included in one system, Information Management System for Official Controls - IMSOC).

The cases covered by the RASFF system illustrate the scale of threats to food safety from the meat and fish products, especially cases of food contamination, while those included in the AAC-FF system, cases of food adulteration, i.e. threats to the economic safety of consumers [28, 29].

The high level of adulteration of meat and fish products is also confirmed by the structure of AACFF system notifications. For example, in 2018, out of 234 cases that were reported to this system, $36.8 \%$ involved adulteration of meat and fish products [37]. In 2019 , these two product groups accounted for $27.0 \%$ of all submissions [36], while in 2020 already 30.0\% [14].

In contrast, under the RASFF System, of the 4,015 notifications in the EU in 2019, 890 cases $(22.2 \%$ of the total) concerned meat and fish products, of which 115 involved adulteration [15]. In 2020, these two product groups accounted for $14.8 \%$ of all notifications [13]. And in 2015, of a total of 3,049 notifications, 632 $(20.7 \%)$ were for meat and fish products. Adulteration concerned 99 cases [16]. Thus, for many years, meat and fish products have accounted for between $15.0 \%$ and $25.0 \%$ of all cases reported to the RASFF. The relatively small number of adulteration cases is a consequence of the specificity of this system, which primarily registers cases of food and forage dangerous to the health and life of consumers, rather than cases of food adulteration. This increased level of adulteration of meat and fish products, as compared to the average for all the food, is also observed on the Polish market.

According to Polish law, a food product is adulterated when its composition is inconsistent with the law, with changes having been made to it, including changes to labelling, aimed at concealing its actual composition or other properties, in particular if: a) procedures have been performed which have changed or concealed its actual composition or appearance; b) the labelling includes a name which does not comply with the provisions of law; c) the labelling includes false data regarding its composition, origin, shelf life or minimum durability date, net content or commercial quality class [38]. This is a broad approach to product counterfeiting, as its scope coincides with the notion of adulteration and mislabelling, which is present in the legislation of other countries (e.g. the USA) ${ }^{4}$.

The research on official food inspections conducted in the years 2005-2020 shows that the average level of irregularities in the scope of the socalled physicochemical parameters (like protein, fat, water, etc.), i.e. those indicating product adulteration in relation to total food, amounted to $14.3 \%$ in this period, which means that almost every seventh batch was adulterated to a lesser or greater extent (Table 1). Meat products accounted for $24.9 \%$ of such batches, while fish products accounted for $23.2 \%$, which is respectively 10.6 and 8.9 percentage points more than for food in general. On the other hand, there were on average $27.5 \%$ mislabelled samples, compared with $37.7 \%$ for meat products and $34.2 \%$ for fish products, which is respectively 10.2 and 6.7 percentage points more than for food in general.

Table 1. Average level of adulteration ${ }^{1)}$ and mislabelling of food on the Polish market between 2005 and 2020 (in \%)

\begin{tabular}{|c|c|c|c|}
\hline & Food in total & $\begin{array}{c}\text { Meat } \\
\text { products }\end{array}$ & $\begin{array}{c}\text { Fish } \\
\text { products }\end{array}$ \\
\hline Adulteration & 14.3 & 24.9 & 23.2 \\
\hline Mislabelling & 27.5 & 37.7 & 34.2 \\
\hline
\end{tabular}

1) - In the table - in order to maintain the comparability of the Polish market research with research results from other countries - the adulteration of the product is understood as irregularities in the scope of the so-called physicochemical parameters (like protein, fat, carbohydrates, water, etc.).

Source: Own calculations based on AFQI inspection results from the relevant years.

Quality irregularities and product adulteration are of a different and variable nature along the supply chain. With respect to fish products, the main ones include:

4 See also the explanation under Table 1. 
(i) at the stage of selling caught fish it is mislabelling of the place of fishing, substitution of wild species with farmed species, or species substitution of fish from within the same family (substitution of more expensive species with cheaper ones [23]; (ii) at the stage of initial processing - overstating the weight of glaze or coating; (iii) at the stage of secondary processing, the range of irregularities is extremely wide, from underweighing of fish flesh, to overweighing vegetable, oil and water additives, and switching fish species; (iv) at the HORECA sector ${ }^{5}$ stage - switching fish species and underweighting fish flesh.

The above examples indicate that the counterfeiting of meat and fish products is a real and serious problem. It requires taking decisive remedial actions, leading to the systematic reduction and elimination of these practices that are harmful to the market and consumers. Given the scale and spatial scope, actions are undertaken at national, regional and global levels. To be effective, however, it is first necessary to recognise the precise ways in which meat and fish products are adulterated and undervalued.

The aspect of the susceptibility of particular product groups to adulteration is frequently addressed in the literature as well as in ongoing discussions $[5,8,22,32]$. In contrast, far less space is devoted to examining the main methods/categories of counterfeiting. Therefore, the basic aim of this study is to determine the dominating methods/categories of food adulteration using the example of two food production sectors, i.e. meat and fish products, in the Polish market.

\section{MATERIAL AND METHODS}

The basic research area in this study are the main methods/categories of adulteration, typical for the studied food processing sectors, i.e. meat and fish products in the Polish market. The study concerned the period from 2010 to 2020 .

The study used the database of the Agricultural and Food Quality Inspection (AFQI), the official food control institution responsible for quality and food adulteration control in Poland.

In order to determine the basic adulteration methods/categories of meat and fish products, the results were examined of all inspections performed by the AFQI in food industry establishments in the years 2010 to 2020 which ended with a positive result, i.e. finding adulteration of a controlled batch/sample ${ }^{6}$

5 HORECA (also Horeca, HoReCa) - term for the food service and hotel industries.

6 A batch of food is a specific quantity of an agri-food item produced, processed, or packaged under the same conditions at a given production facility. A sample is a portion of a food batch taken at one time, in a random manner, for the purpose of inspection or evaluation for quality including adulteration of an agri-food item (Act, 2000). of meat and fish products (the so-called result control, i.e. checks as a result of which financial penalties have been imposed).

In the period from 2010 to 2020 , a total of $1,867 \mathrm{AFQI}$ inspections ended with establishing the adulteration of food products and issuing an administrative decision on imposing a financial penalty on the inspected company (inspection outcome). According to Polish law, all decisions on punishment for food adulteration shall be made public.

Out of the total number of 1,867 identified cases of food adulteration, 507 (27.2 \% of the total) concerned meat and fish products, of which 383 related to meat and 124 to fish. For the 507 controls that ended with establishing adulteration of the examined food, 712 food batches were controlled in total (1.4 batches per one control), from which samples were taken for laboratory tests.

In this study, the results of all 712 inspected batches of meat and fish products were analysed for methods/ categories of product adulteration.

Based on the preliminary analysis of the control test results, a list of methods/categories of adulteration of meat and fish products was compiled. A total of 35 different types of adulteration were identified including 17 common to meat and fish products, 13 typical for meat products only and five for fish products only (Table 2).

Correlation measures, including Pearson linear correlation [1.1] analysis and Spearman's rank correlation, were used to examine similarities in terms of the frequency of occurrence of certain categories of adulteration and food mislabelling irregularities.

$$
r_{x y}=\frac{\sum_{i=1}^{n}\left(x_{i}-\bar{x}\right)\left(y_{i}-\bar{y}\right)}{\sqrt{\sum_{i=1}^{n}\left(x_{i}-\bar{x}\right)^{2}} \sqrt{\sum_{i=1}^{n}\left(y_{i}-\bar{y}\right)^{2}}},
$$

Due to the linearity of the studied dependencies, the Pearson coefficient was used as the basis for inference. Spearman's rank correlation follows the use of variables in rank form, which often leads to an increase in the correlation measure [40], therefore, this measure was used to verify the findings from the first stage of the research as a supplementary measure.

\section{RESULTS AND DISCUSSION}

The methods of food adulteration are a consequence of many factors including: (i) the specificity of individual food industries [24]; (ii) the degree of food product processing - highly processed products (including meat and fish) are more often adulterated due to the difficulty of detecting counterfeiting [3, 22]; (iii) the unit price of a product - the higher the unit price of the product, the more often it is adulterated - branded 
Table 2. List of methods of adulteration of meat and fish products found during AFQI inspections in the years 2010 - 2020

\begin{tabular}{|c|c|c|c|}
\hline Lp. & Methods of adulteration & $\begin{array}{c}\text { Meat } \\
\text { products }\end{array}$ & $\begin{array}{c}\text { Fish } \\
\text { products }\end{array}$ \\
\hline 1. & Omitting some of the ingredients present in the product from the labelling & $\checkmark$ & $\checkmark$ \\
\hline 2. & No list of ingredients for the compound ingredient & $\checkmark$ & $\checkmark$ \\
\hline 3. & Incorrect determination of ingredient content & $\checkmark$ & -- \\
\hline 4. & Presence of raw meat not declared on the labelling & $\checkmark$ & -- \\
\hline 5. & Meat/fish content lower than declared & $\checkmark$ & $\checkmark$ \\
\hline 6. & Displaying ingredients on the labelling not present in the product & $\checkmark$ & $\checkmark$ \\
\hline 7. & Excessive water content in relation to declared & $\checkmark$ & $\checkmark$ \\
\hline 8. & No information on the type of casing used & $\checkmark$ & -- \\
\hline 9. & Higher fat content in comparison to declared & $\checkmark$ & $\checkmark$ \\
\hline 10. & No information on the presence of allergens & $\checkmark$ & $\checkmark$ \\
\hline 11. & Presence of MSM undeclared on the labelling & $\checkmark$ & -- \\
\hline 12. & No information on the animal species of the main raw material & $\checkmark$ & -- \\
\hline 13. & Extension of the best-before date on the labelling & $\checkmark$ & $\checkmark$ \\
\hline 14. & Incorrect product name due to raw material/process used & $\checkmark$ & $\checkmark$ \\
\hline 15. & No information/incorrectly stated country of origin of the raw material ${ }^{1)}$ & $\checkmark$ & $\checkmark$ \\
\hline 16. & Use of two different product names on the labelling & $\checkmark$ & $\checkmark$ \\
\hline 17. & Not indicating ingredients on the labelling in descending order of weight & $\checkmark$ & -- \\
\hline 18. & Providing info on the label that suggests unique properties of the product & $\checkmark$ & $\checkmark$ \\
\hline 19. & Providing contradictory information on the labelling & $\checkmark$ & $\checkmark$ \\
\hline 20. & Protein content lower than declared & $\checkmark$ & $\checkmark$ \\
\hline 21. & MSM content lower than declared & $\checkmark$ & -- \\
\hline 22. & Presence of prohibited substances in the product & $\checkmark$ & -- \\
\hline 23. & No information on quantity/net weight of the product & $\checkmark$ & -- \\
\hline 24. & No information about the primary ingredient & $\checkmark$ & -- \\
\hline 25. & Product net weight lower than declared & $\checkmark$ & $\checkmark$ \\
\hline 26. & No quantitative content of the ingredient used in the product name (QUID) & $\checkmark$ & $\checkmark$ \\
\hline 27. & Excessive salt content in relation to declared & $\checkmark$ & -- \\
\hline 28. & Fat content lower than declared & $\checkmark$ & $\checkmark$ \\
\hline 29. & Listing in the label the ingredient(s) not resulting from the specification & $\checkmark$ & -- \\
\hline 30. & Meat content overstated in relation to declared & $\checkmark$ & -- \\
\hline 31. & Salt content lower than declared & -- & $\checkmark$ \\
\hline 32. & Abnormal organoleptic characteristics of the product & -- & $\checkmark$ \\
\hline 33. & Using fish species different from declared & -- & $\checkmark$ \\
\hline 34. & Incorrect graphics in relation to product composition & -- & $\checkmark$ \\
\hline 35. & Underestimated weight of vegetables in relation to declared & -- & $\checkmark$ \\
\hline
\end{tabular}

$\checkmark$ - such a method of adulteration has been found;

-- - such a method of adulteration has not been found

1) - for fish products: incorrect indication on the label of where the fish was caught

alcohols, organic, traditional, regional products [30]; (iv) the market position of a given food product and its place in the average consumer's diet - usually products that occupy a significant place in the diet are more often adulterated [2, 4]; and finally (v) consumer attitudes and expectations - taking actions to hide ingredients and properties of food products that are undesirable to consumers, or to convince them of the existence of such properties despite their actual absence.

Food adulteration is a serious problem in terms of food safety. However according to the EFSA research (EFSA: Eurobarometr 2019) in terms of food safety, the average Polish consumer is most concerned about antibiotic and hormone residues in meat products $-49 \%$ 
of consumers (44\% on average in the EU-28) and food additives (dyes, preservatives) - $45 \%$ (36\% in the EU28). Far fewer are concerned about pesticide residues in food $-24 \%$ (39\% in EU-28) or contamination with bacteria - 26\% (30\% in the EU - 28). Therefore, Polish consumers perceive, although not the primary problem, the health safety of food (chemical, biological contamination), and they attach less importance to its economic safety (food adulteration). This is probably a consequence of the main criteria determining the choice of a given food item, where taste comes first $58 \%$ of responses ( $49 \%$ in EU-28), price comes second - $53 \%$ of responses $(51 \%$ in the EU-28) [11].

This does not mean, however, that the Polish consumer does not attach any importance to economic safety and food quality. The awareness of the attitudes and expectations of consumers is visible, for example, in the behavior of food producers, including the quality and safety of meat and fish products. Market reputation in the era of strong competition is becoming an increasingly important determinant of companies' strategies in this area.

\section{Meat products}

The conducted research has shown that the basic method of counterfeiting meat and fish products on the Polish market is omitting on the labelling some of the ingredients actually present in the product. The lack of information on the product labelling regarding all ingredients used concerned $23.6 \%$ of the tested batches of meat products and $16.4 \%$ of the fish products (Table
3). The main substances omitted in the ingredient lists of meat and fish products are food additives, especially preservatives and colourants. This is a consequence of the aforementioned exceptional fear of these substances among Polish consumers.

In the case of meat products, a similar category of falsification was the lack of information about the presence of a specific meat ingredient in the product composition, for example, the addition of poultry meat in sausages declared as "pork". This method was found in $8.8 \%$ of the batches of the tested meat products.

In the case of meat products, the second most common method of counterfeiting is the indication of raw materials on the product labelling that are not actually present in the product $(10.2 \%$ of disputed batches). This applies primarily to ingredients sought after by consumers, such as, e.g. better quality types of raw meat (ham, sirloin, loin, etc.), valuable spices, but also, surprisingly, food additives not actually present in the product.

The most frequent adulteration methods of meat products also include the following: incorrect product name due to the raw material or technological process used - e.g. using the term "ham" for a product made of joined pieces of meat or lack of information about the cooking process used for a sausage (8.3\%), lower meat content in comparison to the declaration on the labelling $(7.3 \%)$ and also, which proves not only the lower quality of the product, but also its safety for consumers, lack of information about allergens used (6.0\%) (Figure 1).

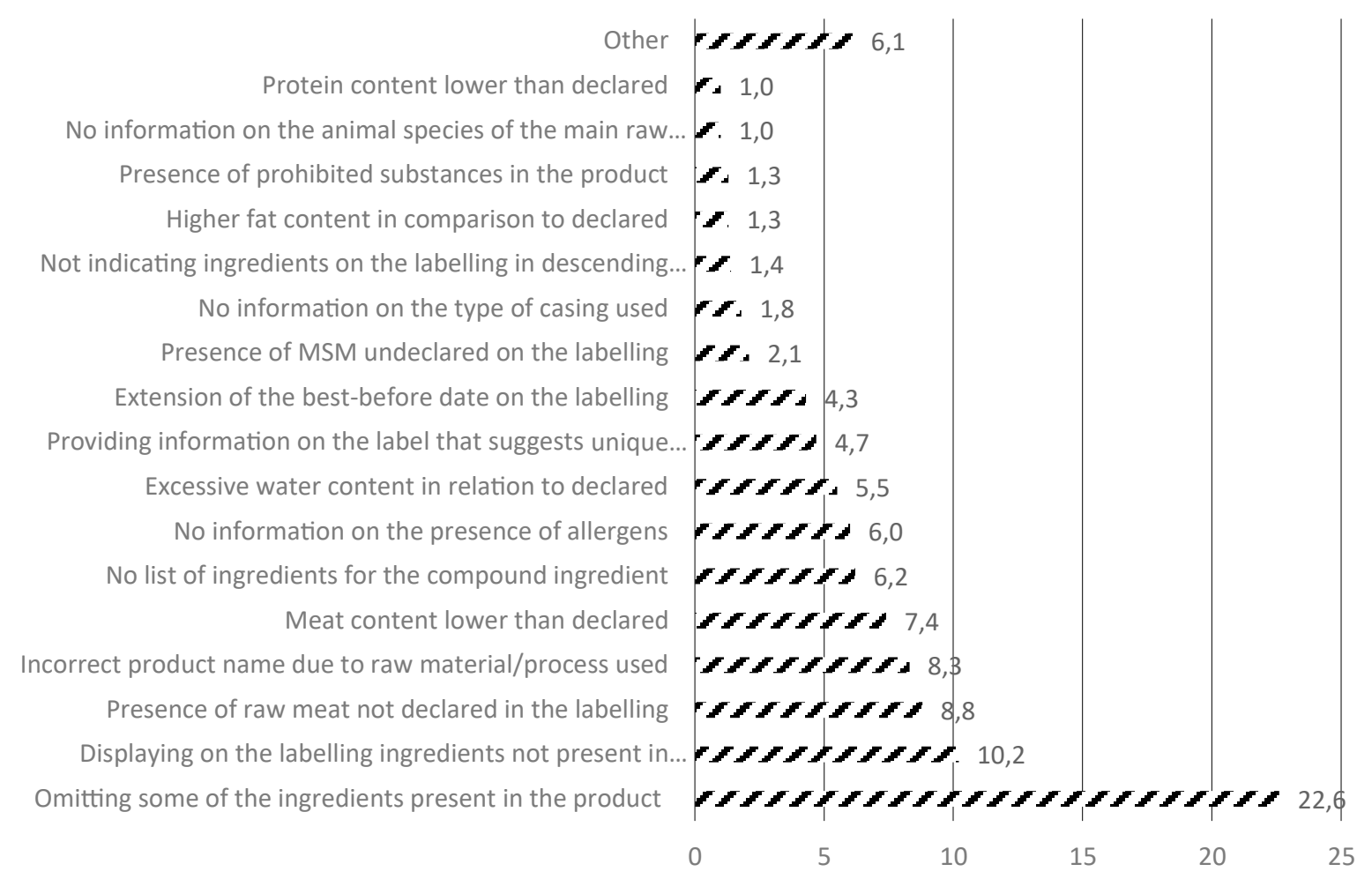

Figure 1. Main methods of adulteration of meat products on the Polish market in 2010-2020 
Table 3. Proportion of each method of adulteration of meat and fish products found during AFQI inspections in the years $2010-2020$ in relation to all irregularities (in \%)

\begin{tabular}{|c|c|c|c|}
\hline Lp. & Methods of adulteration & $\begin{array}{c}\text { Meat } \\
\text { products }\end{array}$ & $\begin{array}{c}\text { Fish } \\
\text { products }\end{array}$ \\
\hline 1. & Omitting from the labelling some of the ingredients present in the product & 22.6 & 16.4 \\
\hline 2. & No list of ingredients for the compound ingredient & 6.2 & 2.6 \\
\hline 3. & Incorrect determination of ingredient content & 0.9 & 1.6 \\
\hline 4. & Presence of raw meat not declared on the labelling & 8.8 & -- \\
\hline 5. & Meat/fish content lower than declared & 7.4 & 18.0 \\
\hline 6. & Displaying ingredients on the labelling not present in the product & 10.2 & 6.3 \\
\hline 7. & Excessive water content in relation to declared & 5.5 & 10.0 \\
\hline 8. & No information on the type of casing used & 1.8 & -- \\
\hline 9. & Higher fat content in comparison to declared & 1.3 & 1.6 \\
\hline 10. & No information on the presence of allergens & 6.0 & 4.3 \\
\hline 11. & Presence of MSM undeclared on the labelling & 2.1 & -- \\
\hline 12. & No information on the animal species of the main raw material & 1.1 & -- \\
\hline 13. & Extension of the best-before date on the labelling & 4.3 & 2.6 \\
\hline 14. & Incorrect product name due to raw material/process used & 8.3 & 7.4 \\
\hline 15. & No information/incorrectly stated country of origin of the main raw material1) & 0.7 & 5.8 \\
\hline 16. & Use of two different product names on the labelling & 0.8 & 1.1 \\
\hline 17. & Not indicating ingredients on the labelling in descending order of weight & 1.4 & -- \\
\hline 18. & Providing information on the label that suggests unique properties of the product & 4.7 & 4.7 \\
\hline 19. & Providing contradictory information on the labelling & 0.3 & 1.1 \\
\hline 20. & Protein content lower than declared & 1.1 & 0.5 \\
\hline 21. & MSM content lower than declared & 0.4 & -- \\
\hline 22. & Presence of prohibited substances in the product & 1.3 & -- \\
\hline 23. & No information on quantity/net weight of the product & 0.5 & - \\
\hline 24. & No information about the primary ingredient & 0.3 & -- \\
\hline 25. & Product net weight lower than declared & 0.1 & 3.7 \\
\hline 26. & No quantitative content of the ingredient used in the product name (QUID) & 0.5 & 1.6 \\
\hline 27. & Excessive salt content in relation to declared & 0.3 & -- \\
\hline 28. & Fat content lower than declared & 0.8 & 1.1 \\
\hline 29. & Listing in the label the ingredient(s) not resulting from the specification & 0.1 & -- \\
\hline 30. & Meat content overstated in relation to declared & 0.3 & -- \\
\hline 31. & Salt content lower than declared & -- & 1.1 \\
\hline 32. & Abnormal organoleptic characteristics of the product & -- & 4.7 \\
\hline 33. & Using fish species different from declared & -- & 2.1 \\
\hline 34. & Incorrect graphics in relation to product composition & -- & 0.6 \\
\hline 35. & Underestimated weight of vegetables in relation to declared & -- & 1.1 \\
\hline 36. & Total & 100.0 & 100.0 \\
\hline
\end{tabular}

One of the relatively frequent methods of adulteration is providing false information on the label suggesting exceptional properties of the product, such as: "homemade", "country", "traditional", "regional" (impersonating products with PDO, PGI, TSG marks") (4.7\% of the examined meat products and the same $4.7 \%$ of fish products).

7 PDO - Protected Designation of Origin, PGI - Protected Geographical Indication, TSG - Traditional Speciality Guaranteed.

\section{Fish products}

As far as fish products are concerned, in addition to the above-mentioned omission of selected ingredients on the product labelling, the most frequent methods of counterfeiting include lowering the fish content of the product $(18.0 \%)$ and the increase in the content of water-oil substances and glaze (10.0\%) associated with the previous method of adulteration.

Overstating the content of water and oily substances, as well as vegetable mixture additives, 
is a typical method of adulterating canned fish, while excessive glaze is a typical method of adulterating frozen fish. As in the case of meat products, one of the important methods of counterfeiting fish products is indicating raw materials on the product label which are not actually present in the product $(6.3 \%$ of questioned batches). In the case of fish products, however, this does not apply only to food additives, but also to vegetables, oil and spices.

Fish product-specific methods of adulteration and the underestimation of its quality include the addition of raw non-value-added fish material (pieces of fish meat, skin, skeleton fragments, etc.). This method is particularly used for canned food, since the type of packaging, which is an "opaque" metal can, makes it impossible for the consumer to assess the composition of the product when making a purchase decision.

\section{General arrangements}

Both meat and fish products are adulterated in many different ways, which is generally not analysed in scientific studies. The addition of "distinct" types of meat (e.g. pork meat in a product declared as poultry) and the substitution of fish species - more expensive ones with cheaper ones - are usually cited as the basic, and in fact the main, methods of adulteration $[7,10]$. Meanwhile, studies conducted have shown many methods and ways of counterfeiting both meat and fish products (Table 3, Figure 1 and Figure 2).
It is worth emphasising that the higher "concentration" of adulteration methods concerns meat products. Although the top five main methods of adulterating these products are responsible for $57.3 \%$ of all counterfeits, and fish - for $58.2 \%$, i.e. at a similar level, the ten main methods of adulteration meat products are responsible for $84.0 \%$ of all counterfeits, while fish - 81.2.

For some of the identified cases of adulteration it is difficult to explain the intention of a given action. This includes, for example, indicating two different product names on the label (e.g. pork sausage/pork ham, or veal sausage/turkey sausage).

Studies have shown that many methods and ways are used for food adulteration, including meat and fish products. Some of them are "universal", which means that they are used to counterfeit various food products, whereas some of them are typical only for selected groups of products, which results from the specific composition of these products and the technologies used for their production.

The share of the main methods of adulteration meat and fish products shows large changes in certain years. For example, the share of the main method of adulteration meat products, i.e. omitting in the labeling some of the ingredients present in the product, ranged from $17.5 \%$ in 2020 to $30.4 \%$ in 2016 (Figure 3). The share of the same method of adulteration in the case of fish products ranged from $16.4 \%$ in 2020 to $31.8 \%$

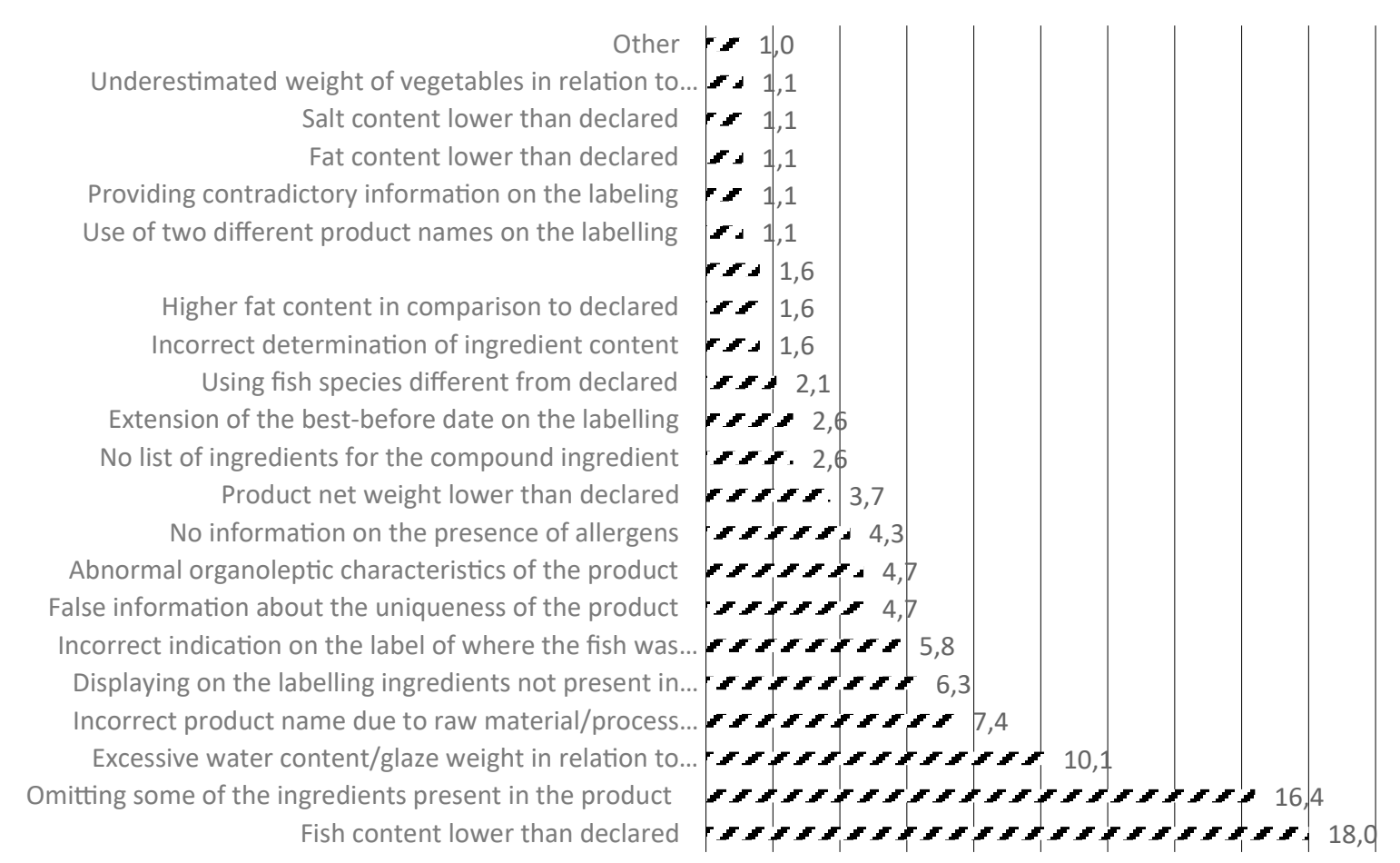

$\begin{array}{lllllllllll}0,0 & 2,0 & 4,0 & 6,0 & 8,0 & 10,0 & 12,0 & 14,0 & 16,0 & 18,0 & 20,0\end{array}$

Figure 2. Main methods of adulteration of fish products on the Polish market in 2010-2020 


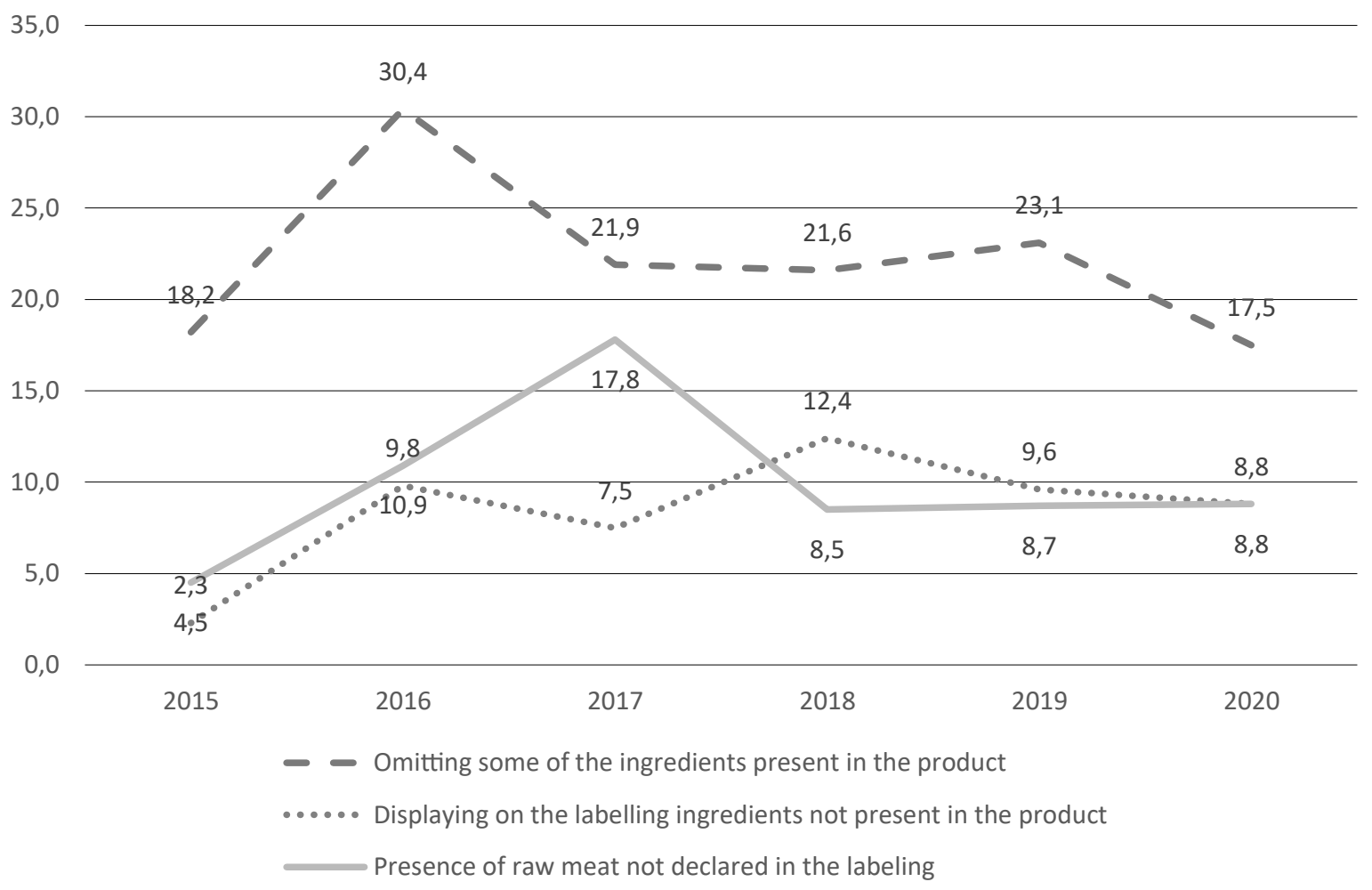

Figure 3. The share of the three main methods of adulteration of meat products on the Polish market in 2010-2020

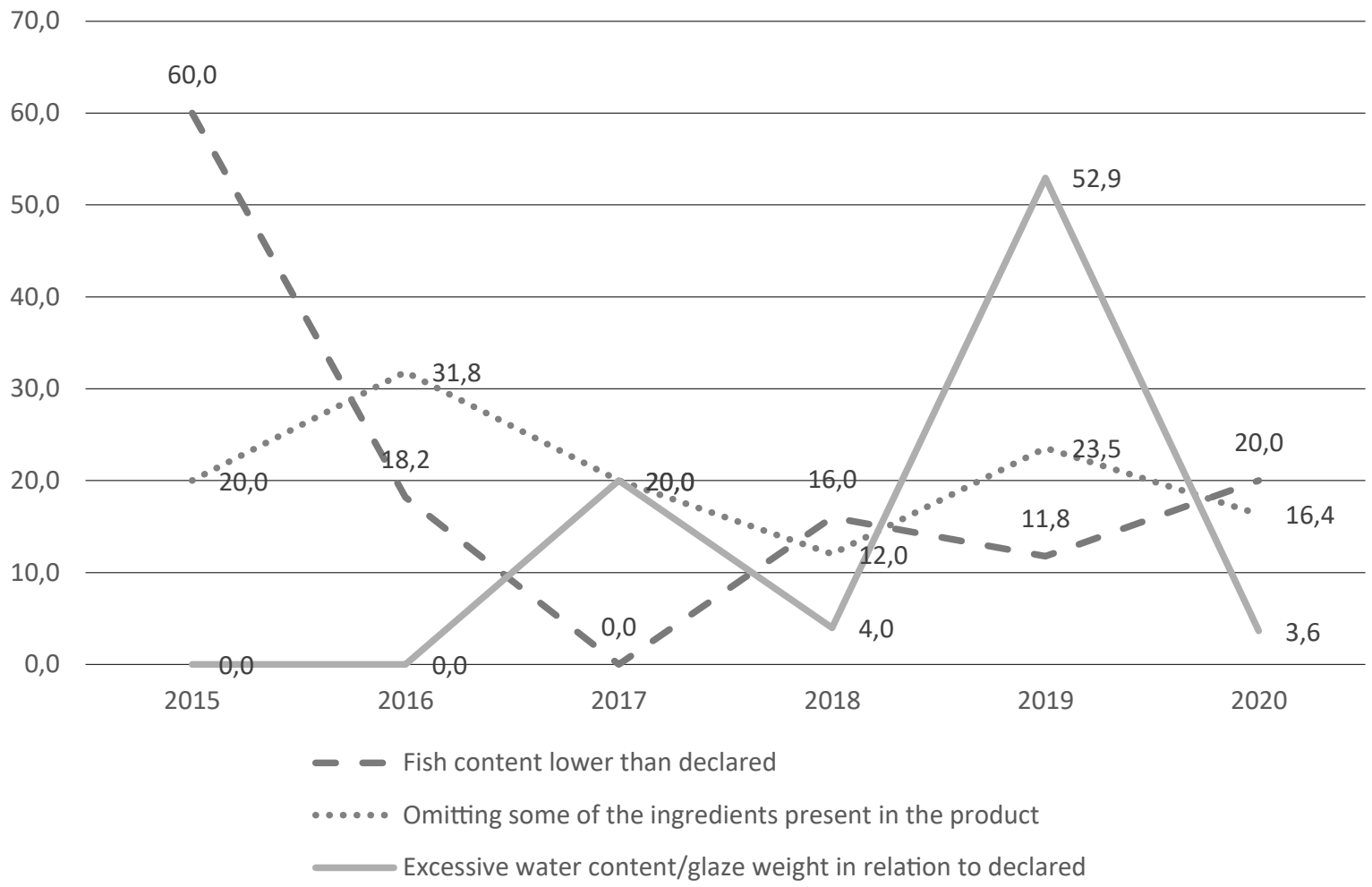

Figure 4. The share of the three main methods of adulteration of fish products on the Polish market in 2010-2020

in 2016. However, the share of the main method of adulteration fish products, i.e. - fish content lower than declared - ranged from $0.0 \%$ in 2017 to $60.0 \%$ in 2015 (Figure 4).
In the case of meat and fish products, despite some differences in the methods of adulteration used, the vast majority of methods are the same. This is confirmed by the correlation coefficient of the distribution of adulteration methods used for these two 
groups of products. The Pearson linear correlation coefficient for the whole examined period (2010-2020) amounted to 0.75 , which indicates the high similarity and frequency of occurrence of the methods used to adulteration these two groups of products (Spearman's rank correlation coefficient for the same period was 0.85 , which confirms the findings regarding the convergence of the analyzed phenomena).

\section{CONCLUSIONS}

The research conducted has shown far-reaching diversity in the methods used to adulterate meat and fish products. Substitution of more expensive ingredients with cheaper ones is extremely common, however, dishonest manufacturers use a much more diversified range of possible methods and ways of adulteration which are therefore more difficult to detect.

There is no reasonable indication that the above illegal practices are limited to the two product groups examined, namely meat and fish. The diversity of adulteration methods used applies to virtually all food groups. Hence, it is reasonable to assume that food adulteration occurs in many different ways, which are often overlooked by control activities or food control institutions are not aware of them. This also applies to consumers.

Given the dynamic nature of international trade and its implications, such as the continuous lengthening of food supply chains, preventing such illegal practices requires cooperation and coordination of efforts at the supra-national level. The complexity and the many layers of commercial relationships in the modern world have been demonstrated by the inspections carried out in the EU countries after the horsemeat scandal.

This means that effective combating of unfair trade practices, such as food adulteration, is possible only through the cooperation of the control services of individual countries.

\section{Conflict of interest}

The author declares no conflict of interest.

\section{REFERENCES}

1. Agnew, D.J., Pearce, J., Pramod, G., Peatman, T., Watson, R., Beddington, J.R. \& Pitcher, T.J.: Estimating the worldwide extent of illegal fishing. PLOS ONE, 2009; 4(2), February 25:108, e4570. https://journals.plos. org/plosone/article?id=10.1371/journal.pone.0004570. doi:org/10.1371/journal.pone.0004570.

2. Azad T., Ahmed S.: Common milk adulteration and their detection techniques, International Journal of Food Contamination, 2016; 3(1):22: 1-9. https://link.springer. com/article/10.1186/s40550-016-0045-3. doi 10.1186/ s40550-016-0045-3.

3. Barnett, J, Begen, F, Howes, S, Regan, A, McConnon, A, Marcu, A, Rowntree, S., Verbeke, W.: Consumers' confidence, reflections and response strategies following the horsemeat incident', Food Control, 2016: vol. 59: 721-730. https://purehost.bath.ac.uk/ws/ portalfiles/portal/138281989/Consumers_confidence etc_Food_Control_for_PURE.pdf. doi: org/10.1016/j. foodcont.2015.06.021.

4. Biswas R.: Adulteration in Milk: A Growing Concern, Journal of Dairy \& Veterinary Sciensies, 2019;9 1, January 11:1-2. https://juniperpublishers.com/ jdvs/pdf/JDVS.MS.ID.555751.pdf . doi: 10.19080/ JDVS.2019.09.555751.

5. CAFIA: Adulteration of food - current problem? Czech Agriculture and Food Inspection Authority, Brno. 2015. https://ec.europa.eu/food/sites/food/files/safety/docs/ official-controls-food-fraud brochure 2015.pdf.

6. Cao Y, Zheng K, Jiang J, Wu J, Shi F, Song X, Jiang $Y$ : A novel method to detect meat adulteration by recombinase polymerase amplification and SYBR green I. Food Chemistry, 2018 November, 15;266:7378. https://pubmed.ncbi.nlm.nih.gov/30381228/. doi: 10.1016/j.foodchem.2018.05.115.

7. Cawthorn D-M., Steinman H., Hoffman L. C.: A high incidence of species substitution and mislabeling detected in meat products sold in South Africa, Food Control, 2013 August; No 32(2):440-449. https:// www.researchgate.net/publication/257399220. doi: org/10.1016/j.foodcont.2013.01.008.

8. Choudhary, A., Gupta, N., Hameed, F., Choton, S.: An overview of food adulteration: Concept, sources, impact, challenges and detection, 2020 January: 8(1) 2564-2573. doi:10.22271/chemi.2020.v8.ilam.8655.

9. Diaz-Bonilla E., Babinard J., Pinstrup-Andersen P., Thomas M.: Globalizing Health Benefits for Developing Countries, International Food Policy Research Institute, Trade and Macroeconomics Division, TMD Discussion Paper, 2002 December: No. 108: 1-68. https://core. ac.uk/download/pdf/6388585.pdf.

10. Di Pinto A., Bottaro M., Bonerba E., Bozzo G., Ceci E., Marchetti P., Mottola A., Tantill G.: Occurrence of mislabeling in meat products using DNA-based assay. Journal of Food Science and Technology, 2014;52(4):2479-84. https://www.researchgate.net/ publication/267331879. doi: 10.1007/s13197-014-1552-y.

11. EFSA. Bezpieczeństwo żywności w UE, Eurobarometr 91.3, 2019 Kwiecień. https://www.efsa.europa. $\mathrm{eu} /$ sites/default/files/corporate_publications/files/ eurobarometer19/country-factsheets/EB91.3_EFSA fact_pl_pl.pdf.

12. Erixon F.: The Economic Benefits of Globalization for Business and Consumers, The European Centre for International Political Economy (ECIPE), 2018, pp. 1-21. https://ecipe.org/wp-content/uploads/2018/01/ Globalization-paper-final.pdf.

13. European Commission: The Rapid Alert System for Food and Feed - Annual Report 2020, Luxembourg, 
2021: 1-40. https://ec.europa.eu/food/system/ files/2021-08/rasff_pub_annual-report_2020.pdf.

14. European Commission: AAC-FF Activity Report 2020, https:/ec.europa.eu/food/system/files/2021-07/foodfraud-reports_20210423_pres-01.pdf.

15. European Commission: RASFF - The Rapid Alert System for Food and Feed - Annual Report 2019, Luxembourg, 2020:1-56. https://op.europa.eu/en/ publication-detail/-/publication/2c5c7729-0c3111eb-bc07-01aa75ed71a1/language-en/format-PDF/ source-174742448. doi:10.2875/993888.

16. European Commission: RASFF - The Rapid Alert System for Food and Feed - Annual Report 2015, Luxembourg, 2016:1-52. https://op.europa.eu/en/ publication-detail/-/publication/98e04cfc-aa5411e6-aab7-01aa75ed71a1/language-en/format-PDF/ source-174743070. doi:10.2875/112129.

17. European Parliament: Report on the food crisis, fraud in the food chain and the control thereof, [2013/2091(INI)], RR $\backslash 1012306 E N . d o c \quad$ PE519.759v03-00. Www. europarl.europa.eu/doceo/document/A-7-2013-0434 EN.htmlt\#part1_def1.

18. FAO, Overview of Food Fraud in the Fisheries sector, FAO Fisheries and Aquaculture Circular, FIAM.C1165, Rome, 2018, ISBN 978-92-5-130402-0.

19. INTERPOL-Europol: Report: Operation OPSON V, 2016 October:1-49, O29 - FP COPY// INTERPOL IGGH, EDOC\#856910. https://www.europol.europa.eu/ publications-documents/operation-opson.

20. INTERPOL-Europol. Report: Operation OPSON VI, 2017 December:1-52. https://www.europol.europa.eu/ publications-documents/operation-opson.

21. INTERPOL-Europol. Report: Operation OPSON VIII, 202012 March:1-40. https://www.europol.europa.eu/ publications-documents/operation-opson.

22. Johnson R.: Food Fraud and "Economically Motivated Adulteration" of Food and Food Ingredients, Congressional Research Service Report, 2014 January10:1-40. https://fas.org/sgp/crs/misc/R43358. pdf.

23. Kappel K., Schröder U.: Substitution of high-priced fish with low-priced species: Adulteration of common sole in German restaurants, Food Control, 2016 January, Volume 59: 478-486. https://www.sciencedirect.com/science/ article/abs/pii/S0956713515300487?via\%3Dihub. doi:10.1016/j.foodcont.2015.06.024.

24. Kowalczyk S.: Bezpieczeństwo i jakość żywności. [Food safety and quality], Wydawnictwo Naukowe PWN, Warszawa, 2016. ISBN 978-83-01-18732-3.

25. Kowalska A.: Ekonomiczne problemy fałszowania żywności. Instrumenty przeciwdziałania. [Economic problems of food adulteration. Counteracting instruments]. Wydawnictwo Uniwersytetu Marii CurieSkłodowskiej, Lublin, 2019. ISBN 978-83-227-9202-5.

26. Marko, P.B., Nance, H.A. \& Guynn, K.D.: Genetic detection of mislabeled fish from a certified sustainable fishery. Current Biology, 2011, Volume 21, Issue 16:621622. https://www.sciencedirect.com/science/article/ pii/S0960982211007755?via\%3Dihub. doi: 10.1016/j. cub.2011.07.006.
27. Meloni, D., Piras, P. \& Mazzette, R... Mislabeling and species substitution in fishery products retailed in Sardinia (Italy), 2009-2014. Italian Journal of Food Safety, 2015, December, Volume 4, No 4: 199-203 . www.pagepressjournals.org/index.php/ijfs/article/view/ ijfs.2015.5363/4938. doi.org/10.4081/ijfs.2015.5363.

28. Mitenius N., Kennedy S.P., Busta F.F.: Food Defense, (in:) Food Safety Management, a Practical Guide for the Food Industry. Y. Motarjemi, H. Lelieveld (ed.), Academic Press, Elsevier - Amsterdam- Boston Heidelberg - London - New York - Oxford - Paris - San Diego - San Francisco -Singapore - Sydney Tokyo, 2014. ISBN: 9780123815040.

29. Moore J.C., Spink J., Lipp M.: Development and Application of a Database of Food Ingredient Fraud and Economically Motivated Adulteration from 1980 to 2010. J Food Sci. 2012;77(4):118-126. https://pubmed. ncbi.nlm.nih.gov/22486545/. doi: 10.1111/j.17503841.2012.02657.x.

30. Nicoletti G., Platania M., Privitera D.: Authentic and Fake Italian Food Products in the World, the 105th EAAE Seminar 'International Marketing and International Trade of Quality Food Products', Bologna, Italy, 2007, March 8-10: 682-690. https://ageconsearch. umn.edu/record/7861/. doi: 10.22004/AG.ECON.7861.

31. Oceana Canada: Mystery fish: seafood fraud in Canada and how to stop it. Oceana Canada, 2017 November. www.oceana.ca/en/publications/reports/mystery-fishseafood-fraud-canada-and-how-stop-it.

32. Pierson, F.: New research reveals food ingredients most prone to fraudulent economically motivated adulteration, US PHARMACOPEIA, News Release, 5-April-2012. HTTPS://WWW.EUREKALERT. ORG/PUB_RELEASES/2012-04/UP-NRR040512. PHP.

33. Robertson A., Tirado C., Lobstein T., Jermini M., Knai C., Jensen J. H., Ferro-Luzzi A., James W.P.T.: Food and Health in Europe: A New Basis for Action,WHO Regional Publications, European Series, No. 96, Copenhagen 2004. https://www.euro.who.int/_data/ assets/pdf_file/0005/74417/E82161.pdf.

34. Stevens $\bar{W}$ : The Risks and Opportunities from Globalisation. New Zealand Treasury, Working Paper, 2007 July, 07/05: 1-61. https://www.treasury.govt.nz/ sites/default/files/2007-10/twp07-05.pdf. ISSN 11769505.

35. Tembe D., Mukaratirwa S., Zishiri O. T.: Undeclared Meat Species in Processed Meat Products from Retail Franchises in the Durban Metropole, KwaZulu-Natal Province, South Africa, Using Species-specific DNA Primers, Food Protection Trends, 2018, Vol 38, No. 6: 440-449. https://www.foodprotection.org/files/foodprotection-trends/nov-dec-18-tembe.pdf.

36. The European Commission: The EU Food Fraud Network and the Administrative Assistance and Cooperation System, Annual Report 2019, Luxembourg: Publications Office of the European Union, 2020: 1-15. doi:10.2875/326318.

37. The European Commission: The EU Food Fraud Network and the Administrative Assistance and 
Cooperation System, Annual Report 2018, Luxembourg: Publications Office of the European Union, 2019: 1-16. https://ec.europa.eu/food/system/files/2020-05/ff ffn annual-report_2018.pdf.

38. Ustawa z dnia 21 grudnia 2000 r. o jakości handlowe artykułów rolno-spożywczych (Dziennik Ustaw 2001 $\mathrm{Nr} 5$ poz. 44).

39. Weiß J., Sachs A., Weinelt H.: 2018 Globalization Report: Who Benefits Most from Globalization? Bertelsmann Stiftung, GED-Team, 2018:1-78. http://www.iberglobal. com/files/2018-2/MT_Globalization_Report_2018.pdf.

40. Wiśniewski J. W.: Dylematy stosowania współczynnika korelacji Spearmana. W: Zarządzanie ryzykiem kapitałowym i ubezpieczeniowym oraz społecznymi uwarunkowaniami ryzyka rynku pracy, Szkutnik $W$. (red): Studia Ekonomiczne: Zeszyty Naukowe Uniwersytetu Ekonomicznego w Katowicach, 2014, nr
181:174-184. https://www.ue.katowice.pl/fileadmin.pdf. ISSN 2083-861.

41. Xiong, X., Guardone, L., Cornax, M.J., Tinacci, L., Guidi, A., Gianfaldoni, D. \& Armani, A.: DNA barcoding reveals substitution of Sablefish (Anoplopoma fimbria) with Patagonian and Antarctic Toothfish (Dissostichus eleginoides and Dissostichus mawsoni) in online market in China: How mislabeling opens door to IUU fishing. Food Control, 2016;70:380391. https:/www.sciencedirect.com/science/article/abs/ pii/S0956713516303176?via\%3Dihub. doi.org/10.1016/j. foodcont.2016.06.010.

Received: 08.09 .2021

Accepted: 18.10.2021

Published online first: 22.10.2021 